\title{
Collaborative Planning and Teaching English Vocabulary with Virtual Reality: A Community Service in SD Gunung Batu Cianjur
}

\section{Elis Homsini Maolida ${ }^{1 *}$, Aji Mulyana ${ }^{2}$, Siti Rahma R ${ }^{3}$, Elsa Adetia ${ }^{4}$, Anzalna Rizki ${ }^{5}$}

1,2,3,4,5 Universitas Suryakancana, Jl. Pasir Gede Raya 43216, Bojongherang, Cianjur, Provinsi Jawa Barat, Indonesia.

Corresponding Email: elishomsini@unsur.ac.id ${ }^{1 *}$.

\section{Article History:}

Received: Dec 30th 2021

Revised: Jan 06th 2022

Accepted: Jan 11th 2022

Published: Jan 29th 2022

Keywords: Virtual Reality; Community Service;

Collaborative Teaching; English Vocabulary; Teaching English to Young Learners.
Abstract: This community service is part of a larger project of teachers' and student teachers' training and focuses group discussion to utilize the technology of virtual reality (VR) in learning English vocabulary in fifteen elementary schools in Cipanas Cianjur. This paper focuses on the implementation of collaborative planning and teaching between a teacher and three student teachers under the supervision of a teacher educator in integrating virtual reality to teach English vocabulary to 41 young learners in SD Gunung Batu. As a result of collaboration on integrating $V R$ in vocabulary teaching, young learners' vocabulary outcome improved with pre-test mean score was 55.8 and post-test mean score were 95.6. In addition, the teacher and student teachers also show an ability to design lesson plan as well as collaboratively implement it in the classroom. 


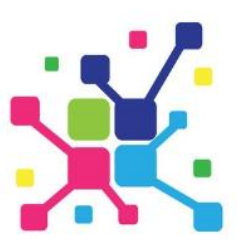

\section{Introduction}

In English as Foreign Language (EFL) context, EFL vocabulary learning is very important to learn at young ages [1]. In this case, Tomasello (2019) refers vocabulary learning as word learning, a smaller linguistic lesson, where objects are shown to young learners so they can connect the term to what they hear or relate the words to concrete entities [2]. Regarding this, young learners' experience of L1 or first language [3] and the second language (L2)'s features and linguistic input, both are important [4]. It is also important to note that teaching vocabulary to young learners is not similar with teaching vocabulary to adult learners. Veronika et al (2018) explain that young learners are unique with interesting characteristics, therefore high creativity, innovations, and fresh ideas are required to teach English at this level [5]. They also highlight the important role of playing in acquiring new things and maintain their motivation. Consequently, facilitating young learners with an interactive learning technique and application is needed. In this case, Language activities that are engaging, fascinating, and motivational, such as using interactive technology, should be used to boost their verbal attempts.

Moreover, in today's Industry Revolution 4.0 period, the use of technology plays a vital part in producing a more effective and innovative educational practice and helps students improve their English skills [6]. In this case, Indonesian students need a new learning medium that can help them integrate their skills and is based on their alpha generation nature. In this scenario, the Alpha generation is more likely to be a visual learner who visualizes their subject to help them remember it. Additionally, visualizing the content will aid them in concentrating and maintain their interest in learning [7]. Those merits of technology make it a crucial instructional and supportive tool [8]. Furthermore, technology offers a variety of ways to make teaching more engaging and useful [9]. In this regard, Solanki and Shyamlee (2012) suggested that technology satisfies both the visual and aural senses of learners [10].

Virtual reality, or VR, is a three-dimensional technology that is immersive, realistic, and can deliver actual experiences to activate and engage passive learners by bringing reality to the classroom [11]. By using Virtual Reality, young learners get new learning experiences and interesting activities by feeling as if the objects they see real [12]. However, the benefits of technology (virtual reality in this context of community service) are depending on how teachers employ it in their language classrooms [13]. Even if they are not computer experts, teachers should discover ways to use technology as a positive learning tool for their learners. As a result, to meet the current language instruction need, a tech-savvy language teacher must regularly update and extend pedagogical and technological knowledge and skills, particularly when instructing young learners.

The TPACK (Technological Pedagogical Content Knowledge) framework introduces a new technique and paradigm for global teacher knowledge to enable 


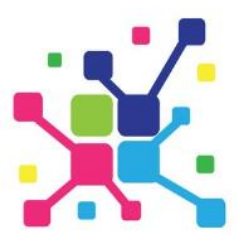

A J A D

Jurnal Pengabdian kepada Masyarakat

Vol. 2, No. 1, May, 2022, pp. 73-81

DOI : https://doi.org/10.35870/ajad.v2i1.40

effective technology-enhanced education [14]. Another study by Cahyono and Kurnianti (2016) indicated that taking a TPACK-oriented teaching practice course can assist Indonesian EFL teachers in improving the quality of their EFL instructional designs and practices [15]. This TPACK oriented training is also critical because many teachers are still grappling with the use of technology to enhance teaching and learning processes [16]. This problem must be addressed through workshops and trainings so that teachers can adjust to the rapid change of era which Kasali refers as "changed or die" [17].

Regarding those abovementioned issues, this community service was initiated and carried out to achieve two main targets: first, to improve teachers' pedagogical and technological knowledge through collaborative planning (done in trainings and FGD sessions) and teaching (done in real classroom) and second the result will affect the students' vocabulary outcome. This paper will limit its scope to emphasis the report on collaborative planning and teaching process of the teacher and student teachers and the result that will be determined from students' learning outcome.

\section{Method}

a. Activity Implementation Method

As mentioned earlier, this community service is a part of larger project of TPACK based teachers training to integrate VR technology in teaching English vocabulary to young learners. This report covers how the trainings facilitate the teacher and student teachers to collaborate to create lesson plan and implement the plan in the classroom and how the result was evidenced in students' vocabulary test outcome.

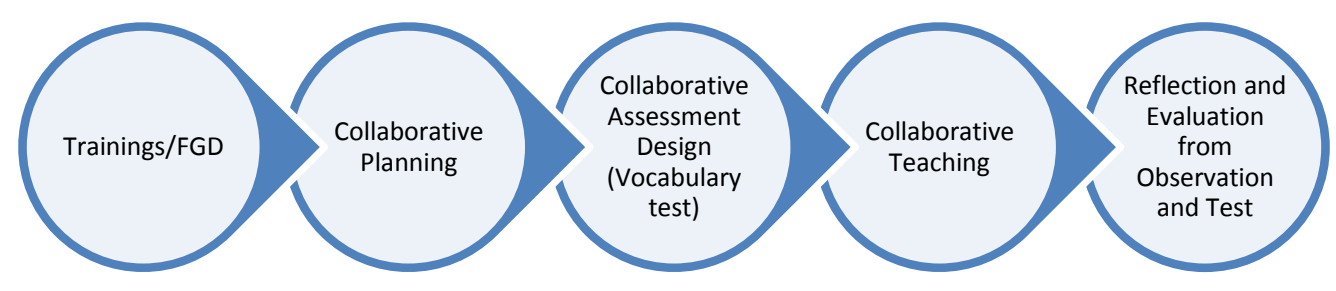

Figure 1. Stages of Community Service

The figure shows the stages of community service. It was started with trainings and FGDs that facilitate the elementary school teacher to collaborate with student teachers, applying what they got from the trainings in a form of lesson plan to integrate VR in vocabulary teaching. Then the collaboration extended to asynchronous and synchronous discussion on developing assessment for the lesson. After that, the student teacher and the teacher collaborated to teach vocabulary by using virtual reality and the result can be seen from the young learners' learning output in the form of vocabulary test result. 
This study focuses on reporting community service through collaborative planning and teaching between SD Gunung Batu teacher with student teachers under the supervision of teacher educator and the assigned trainers. The teacher was not an English teacher, but he was assigned by school to participate in the workshop as well as in collaborative teaching so he can share the experience with other teachers. The student teachers were $3^{\text {rd }}$ semester students in faculty of education and training, Suryakancana university. Meanwhile, the young learners were $5^{\text {th }}$ grade students with Sundanese and Indonesian as their first language.

\section{b. Effective Time of Activity Implementation}

This community service was carried out for a week, starting with several face-to-face training sessions and FGD sessions with teacher participants from 15 elementary schools, 15 teacher educators from Suryakancana University and 45 student teachers from FKIP Suryakancana. University on Tuesday (21 December 2021) and Thursday (23 December 2021).

\section{c. Activity Place}

This community service was carried out for a week, starting with several face-to-face training sessions and FGD sessions with teacher participants from 15 elementary schools, 15 teacher educators from Suryakancana University and 45 student teachers from FKIP Suryakancana. University. The workshop and FGD were held in the Suryakancana University auditorium. Then, collaborative assessment and test development are carried out asynchronously or synchronously through WhatsApp groups and zoom sessions. After that, two face-to-face interactions for teaching vocabulary by integrating virtual reality were carried out to 41 young students at SD Gunung Batu, Cipanas Cianjur. It must be admitted that the school does not have English lessons as local content so that this program is recognized as inspiring stakeholders to choose English as one of the local content in schools.

\section{Result and Discussion}

This part discusses the process of collaborative planning and teaching English vocabulary with virtual reality to young learners.

\section{Collaborative Planning}

Collaborative planning between the teacher and the student teachers was carried out during training and focus group discussion session. After the trainers shared the materials, the teachers and student teachers were asked to collaboratively plan the lesson by integrating the content they got from the trainers. There were two main contents in the training sessions: first, the content focusing on principles, techniques, and methods of teaching vocabulary to young learners and the second, the content 


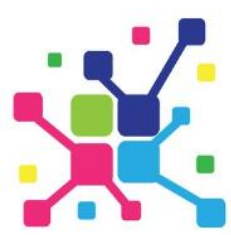

A J A D

Jurnal Pengabdian kepada Masyarakat

Vol. 2, No. 1, May, 2022, pp. 73-81

DOI : https://doi.org/10.35870/ajad.v2i1.40

focusing on virtual reality integration in teaching vocabulary. The teacher, as well as the student teachers, were also involved to try the virtual reality to feel and to experience how it worked.
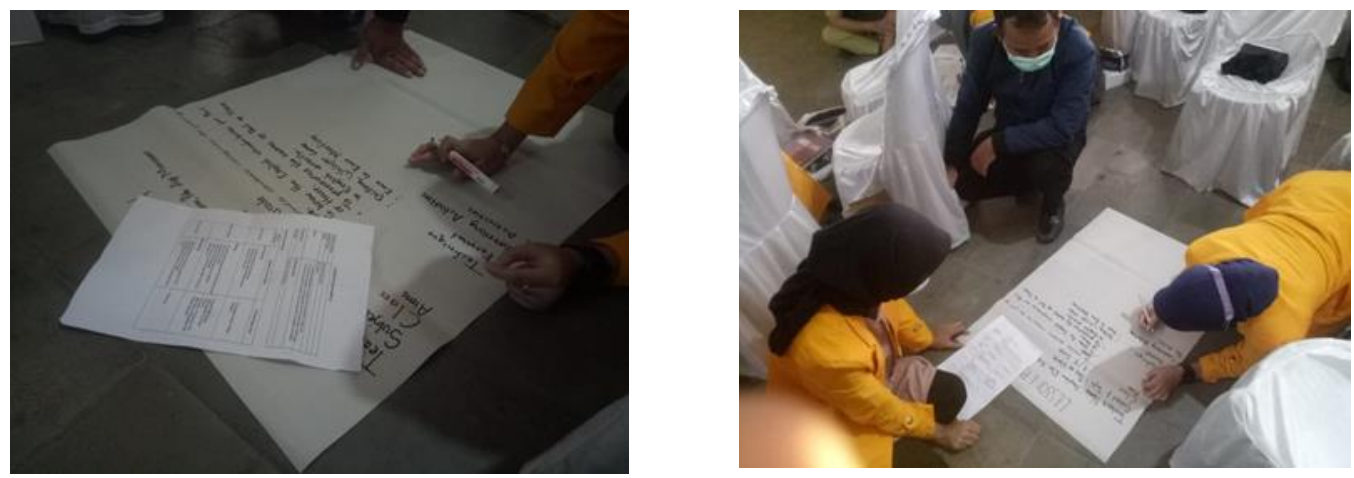

Figure 2. Teacher and Student Teachers Collaboratively Planned the Lesson

In this context of community service report, the focus is on collaborative planning between the teacher from SD Gunung Batu with the student teachers. In the beginning, they planned to integrate virtual reality in teaching two topics: colors and things at home. However, considering the topic of color might be too easy for fifth graders, the topic was focused on things at home with two different categories: Things at home part 1 and things at home part 2. In this collaboration, however, the student teachers were more dominant and active in sharing their ideas. It was because, the teacher who came from non-English background assumed that the student teachers who came from English background were more experienced than the teacher. It was good that the student teachers kept asking and confirming to the teacher whether the topic, the technique, and the material would work or not so the teacher had equal important role in the collaborative planning.

As a result, planning for meeting 1 and planning for meeting 2 were designed with some details, including the aims of the lesson, items/vocabularies they were going to teach, the media, the technique, timing, and most importantly, the steps and the stages of teaching.

\section{Collaborative Teaching}

A pre-test was conducted before the collaborative teaching carried out. In this case, the result of collaborative design of the test was used to look at the young learners' vocabulary skill. After the pre-test, the teaching was conducted led by student teachers with the teacher aided to manage young learners and classroom. In the beginning the teachers showed some pictures of things at home (part 1) and asked the learners to mention the picture they saw, then with some interactive and drilling activity the learners reviewed the vocabularies. Then the teachers distributed the virtual realities, one VR for one group, and in the group the learners took turn to see the things at home in 360 videos while the other wrote the list of vocabularies. From the result of reflection 


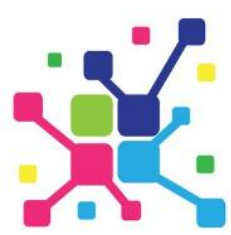

A J A D

Jurnal Pengabdian kepada Masyarakat

Vol. 2, No. 1, May, 2022, pp. 73-81

DOI : https://doi.org/10.35870/ajad.v2i1.40

in meeting 1, it was admitted that the teaching was not as successful as they expected. It was because the class started too late due to technical problems encountered by two student teachers. In addition, technical issue of lacking smartphones that supported the VR was another problem that made the learners waited too long before they learnt.

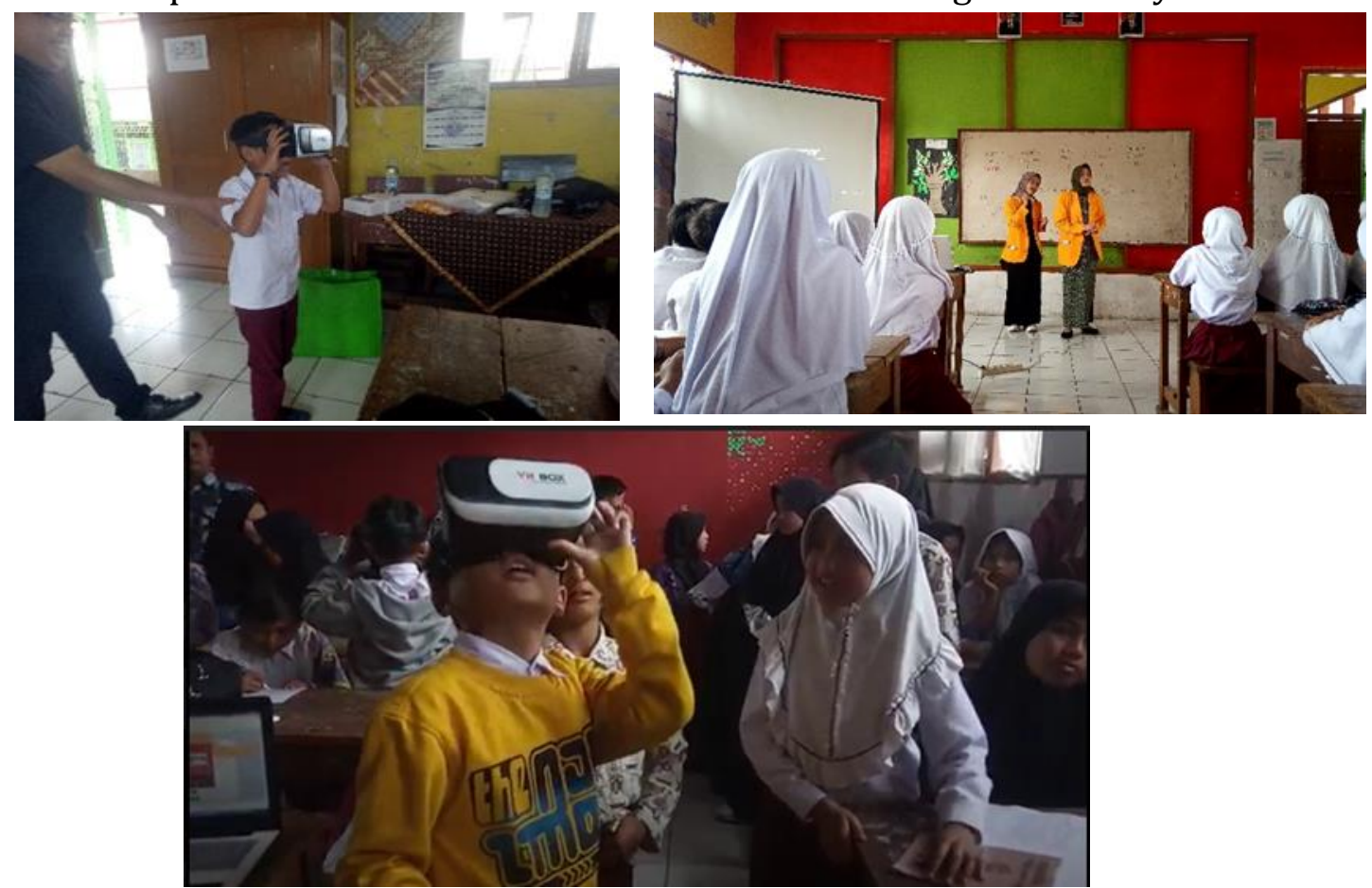

Figure 3. Teaching Vocabulary with Virtual Reality

Learning from those problems, meeting 2 was better prepared by making sure the student teachers came in time, even before the learners started coming, because they knew that integrating VR needed some time to prepare and manage. In meeting 2, the classroom activities were also more varied. In the beginning, the teachers played a song related with things at home and when the song paused, a learner mentioned one of things at home they memorized from pervious lesson. Then, another interactive activity was also added along with introduction to new vocabularies (things at home part 2). When VR was integrated, the learners did not only observe and write the vocabularies but also presented it in front of their classmates. The review was done interactively. As a post session, a post test was conducted to see if the learners made some improvement on their vocabulary outputs. What can be observed from meeting 2 was the teacher's more involvement in managing the class and helping with virtual reality integration in learning vocabulary.

\section{Reflection and Evaluation}

From the result of observation and documentation, the teacher and student teachers have shown a skill of designing lesson plan by fulfilling all main aspects required in the lesson plan. The second, the teachers and the student teachers could 


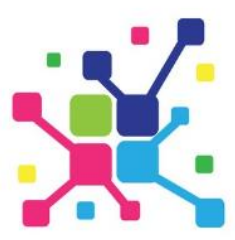

A J A D

Jurnal Pengabdian kepada Masyarakat

Vol. 2, No. 1, May, 2022, pp. 73-81

DOI : https://doi.org/10.35870/ajad.v2i1.40

show a collaborative work of integrating visual reality in teaching vocabulary by utilizing various techniques and strategies, also encouraged students to do collaborative task.

The result of collaborative planning and teaching vocabulary by using virtual reality was also shown from the result of learners' vocabulary output taken from the result of posttest. By utilizing paired T-test, the result shows that there was mean difference between pre-test and post test result.

Table 1. Paired Samples Statistics

\begin{tabular}{|l|l|r|r|r|r|}
\hline \multicolumn{2}{|l|}{} & \multicolumn{1}{|c|}{ Mean } & N & Std. Deviation & Std. Error Mean \\
\hline Pair 1 & BeforeVR & 55.80 & 41 & 8.530 & 1.332 \\
& AfterVR & 95.61 & 41 & 5.044 & .788 \\
\hline
\end{tabular}

From the descriptive table, it can be seen that the sample number was 41 and the mean score before the Virtual reality teaching collaboration was 55.80 and the mean score after the VR teaching collaboration was 95.61. Since the mean score of pre-test 55.80 < post-test 95.61, it can be said that descriptively there was a mean difference between pre-test and post -test. To determine if the difference was significant, we can look at the following result of paired samples test:

Table 2. Paired Samples Test

\begin{tabular}{|c|c|c|c|c|c|c|c|c|c|}
\hline & \multicolumn{5}{|c|}{ Paired Differences } & \multirow[b]{3}{*}{$\mathrm{t}$} & \multirow[b]{3}{*}{$\mathrm{df}$} & \multirow{3}{*}{$\begin{array}{l}\text { Sig. (2- } \\
\text { tailed) }\end{array}$} \\
\hline & & \multirow[b]{2}{*}{ Mean } & \multirow{2}{*}{$\begin{array}{c}\text { Std. } \\
\text { Deviation }\end{array}$} & \multirow{2}{*}{$\begin{array}{l}\text { Std. } \\
\text { Error } \\
\text { Mean }\end{array}$} & \multicolumn{2}{|c|}{$\begin{array}{c}\text { 95\% Confidence } \\
\text { Interval of the } \\
\text { Difference }\end{array}$} & & & \\
\hline & & & & & Lower & Upper & & & \\
\hline $\begin{array}{l}\text { Pair } \\
1\end{array}$ & $\begin{array}{l}\text { BeforeVR } \\
\text { - AfterVR }\end{array}$ & -39.805 & 9.163 & 1.431 & -42.697 & -36.913 & -27.816 & 40 & .000 \\
\hline
\end{tabular}

From the result of paired samples Test with 95\% of confidence level, the mean difference was 39.805 and it was significant since Sig. value (2-tailed) was $<0.05(.000)$. It shows that $\mathrm{HO}$ was rejected and Ha was accepted so there was a mean difference and it was significant. Therefore, it can be said that the collaborative teaching of integrating VR in vocabulary learning gave has influenced students' vocabulary output.

\section{Conclusion}

Facilitating collaborative planning and teaching is essential to do in teacher training and FGD. Beside getting familiar with principles, techniques, and methos in teaching vocabulary to young learners as well as knowing how to integrate Virtual Reality in teaching vocabulary, the teacher also has practical experience to show what 


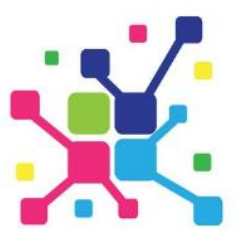

A J A D

Jurnal Pengabdian kepada Masyarakat

Vol. 2, No. 1, May, 2022, pp. 73-81

DOI : https://doi.org/10.35870/ajad.v2i1.40

they understand by sharing their knowledge and experience, also working hand in hand with student teachers to plan the lesson. Furthermore, the teacher and student teachers also have a constructive opportunity to implement their collaborative plan into collaborative teaching in real English classroom for young learners to see how it works and to reveal its result. Despite some challenges in its implementation, the young learners' post test result shows a significant influence showing the potential contribution of the use of Virtual Reality in Teaching Vocabulary resulted from collaborative planning and teaching between teacher and student teachers.

\section{Acknowledgements}

We would extend our sincerest gratitude to Kementerian Pendidikan, Kebudayaan, Riset, dan Teknologi for funding this MBKM policy and research-based community service. We also would like to extend our appreciation to Dinas Pendidikan Kabupaten Cianjur, LPPM Universitas Suryakancana, SDN Gunung Batu and all parties that could not be mentioned one by one for supporting this study.

\section{References}

[1] Kimsesiz, F., 2017. The Effect of Project Based Learning in Teaching EFL Vocabulary to Young Learners of English: The Case of Pre-School Children. Online Submission, 5(4), pp.426-439.

[2] Tomasello, M. ed., 2019. The New Psychology of Language: Cognitive and Functional Approaches To Language Structure, Volume II. Psychology Press

[3] Cameron, L., 2001. Teaching languages to young learners. Ernst Klett Sprachen.

[4] Cook, V., 2016. Second language learning and language teaching. Routledge.

[5] Veronica, U.P., Nurnaningsih, A.A. and Astuti, P.I., 2018. Learning English Vocabulary through Online Games: Case Study of Students In 4th Grade of State Elementary School (SDN) Jombor 01, Sukoharjo, Central Java, Indonesia.International Journal of Multicultural and Multireligious Understanding, 5(4), pp.470-477.

[6] Puncreobutr, V., 2016. Education 4.0: New challenge of learning. St. Theresa Journal of Humanities and Social Sciences, 2(2).

[7] dos Reis, T.A., 2018. Study on the alpha generation and the reflections of its behavior in the organizational environment. Quest Journals J Res Humanit Soc Sci, 6, pp.9-19. 
[8] Qizi, K. D. S. 2021. THE USE OF TECHNOLOGY IN ENGLISH LANGUAGE LEARNING. In Euro-Asia Conferences. pp. 124-127.

[9] Patel, C., 2013. Use of multimedia technology in teaching and learning communication skill: An analysis. International Journal of Advancements in Research \& Technology, 2(7), pp.116-123.

[10] Shyamlee, S.D. and Phil, M., 2012, March. Use of technology in English language teaching and learning: An analysis. In International Conference on Language, Medias and Culture (Vol. 33, No. 1, pp. 150-156).

[11] Utami, L.P.R.A., Suwastini, N.K.A., Dantes, G.R., Suprihatin, C.T. and Adnyani, K.E.K., 2021. VIRTUAL REALITY FOR SUPPORTING AUTHENTIC LEARNING IN 21ST CENTURY LANGUAGE CLASSROOM. Jurnal Pendidikan Teknologi dan Kejuruan, 18(1), pp.132-141.

[12] Dharma, K.Y., Sugihartini, N. and Arthana, I.K.R., 2018. Pengaruh Penggunaan Media Virtual Reality Dengan Model Pembelajaran Klasikal Terhadap Hasil Belajar Siswa Di Tk Negeri Pembina Singaraja.Jurnal Pendidikan Teknologi dan Kejuruan, 15(2).

[13] Bransford, J., Cocking, R.R. and Brown, A.L., 2000. How people learn: Brain, mind, experience, and school. Expanded edition. National Academies Press.

[14] Koehler, M. and Mishra, P., 2009. What is technological pedagogical content knowledge (TPACK)?. Contemporary issues in technology and teacher education, 9(1), pp.60-70.

[15] Cahyono, B.Y., Kurnianti, O.D. and Mutiaraningrum, I., 2016. Indonesian EFL teachers' application of TPACK in in-service education teaching practices. International Journal of English Language Teaching, 4(5), pp.16-30.

[16] Rosa, J.D., 2016. Experiences, perceptions and attitudes on ICT integration: A case study among novice and experienced language teachers in the Philippines. International Journal of Education and Development using ICT, 12(3).

[17] Kasali, R. 2018. The Great Shifting. Jakarta: Gramedia. 